\title{
PENCAK SILAT PANGLIPUR TINJAUAN SEJARAH BUDAYA
}

\author{
Oleh M. Halwi Dahlan \\ Balai Pelestarian Sejarah dan Nilai Tradisional Bandung \\ Jln. Cinambo No. 136 Ujungberung Bandung \\ Email: karaengalwi@gmail.com
}

Naskah diterima: 3 Maret 2011

Naskah disetujui: 29 April 2011

\begin{abstract}
Abstrak
Panglipur adalah salah satu perguruan silat yang didirikan oleh Abah Aleh pada tahun 1909 di Bandung. Dalam perkembangannya pendekar-pendekar Panglipur turut berjuang mempertahankan kemerdekaan Indonesia khususnya pada masa revolusi kemerdekaan. Kepemimpinan Panglipur diserahkan Abah Aleh kepada puteranya bernama Udi, namun perwira muda Angkatan Udara ini meninggal dunia. Abah Aleh kemudian menyerahkan kepemimpinan kepada putri keempatnya Rd. Enny Rukmini. Pada masa kepemimpinan Rd. Enny Rukmini dibantu beberapa murid senior Panglipur mengalami perkembangan. Penelitian ini mendiskripsikan tentang lahir dan berkembangnya Perguruan Silat Panglipur berdasarkan studi pustaka dan wawancara dengan pewaris perguruan tersebut serta dengan beberapa murid Perguruan Pencak Silat Panglipur dari berbagai tingkatan. Kini Pencak Silat Panglipur tidak hanya berkembang di Asia, tetapi juga di Eropa.
\end{abstract}

Kata Kunci: pencak silat, Panglipur

\section{Abstract}

Panglipur is the name of traditional martial art institution founded by Abah Aleh in Bandung in 1909. Its pendekar (warrior) have important role in defending our independence, especially during our independence revolution. Panglipur made great progress under Rd. Enny Rukmini, the fourth daughter of Abah Aleh. This research tries to describe the birth and development of Perguruan Silat Panglipur based on bibliographical study and in-depth interview with the heirs of the institution and some disciples from various levels. Today, Perguruan Silat Panglipur has spread to as far as Europe.

Keywords: pencak silat, Panglipur 


\section{A. PENDAHULUAN}

Panglipur sebuah nama organisasi perkumpulan pesilat sekaligus nama sebuah perguruan silat tradisional. Panglipur adalah salah satu seni beladiri khas Indonesia yang diperoleh dengan cara menggabungkan beberapa jurus andalan dari beberapa pendekar sezaman yang juga berasal dari bumi nusantara.

Penulisan tentang perguruan silat di Indonesia sangat minim, ada perguruan berinisiatif menulis sendiri riwayat perguruannya seperti Merpati Putih, Tapak Suci, dan Margaluyu. Ada pula yang baru dalam taraf penyusunan seperti Cikalong dan Sahbandar, tetapi banyak yang sudah memulai penulisan di dunia maya. Langkah-langkah ini sangat baik sebagai bahan penelitian atau menjadi ajang diskusi tentang seni beladiri tradisional milik Indonesia.

Di antara yang telah merambah dunia maya dan masih dalam penyusunan adalah aliran silat yang bernama Panglipur(Rahman, wawancara, 29 April 2009), suatu seni beladiri tradisional sekaligus nama sebuah perguruan silat milik Indonesia yang saat ini berpusat di Kampung Sumursari Desa Sukasono Kecamatan Wanaraja Kabupaten Garut Provinsi Jawa Barat, tetapi pusat Himpunan Pencak Silat (HPS) Panglipur berpusat di J1. Imam Bonjol No. 38 Bandung.

Bagaimanakah awal pembentukan Perguruan Pencak Silat Panglipur? Bagaimana pula perkembangannya? Pertanyaan pokok ini kemudian dirumuskan menjadi beberapa pertanyaan seperti: Siapakah pendiri Perguruan Pencak Silat Panglipur? Mengapa dinamakan Panglipur? Bagaimana regenerasi di tubuh perguruan silat tersebut? Jurus apa saja yang digunakan?
Bagaimana perkembangan jurus-jurus tersebut? Bagaimana pola perkembangan dan persebaran perguruan tersebut? Dari pertanyaan-pertanyaan tersebut penulis kemudian melakukan penelitian tentang perguruan ini.

Tempat pelaksanaan penelitian di Kabupaten Garut Provinsi Jawa Barat dengan 2 alasan. Pertama, karena pusat perguruan silat Panglipur berada di wilayah ini yaitu di Kampung Sumursari Desa Sukasono Kecamatan Wanaraja Kabupaten Garut. Padepokan Panglipur di tempat ini selain sebagai pusat latihan (selain di pusat-pusat latihan lainnya - biasanya disebut cabang Panglipur) juga menjadi pusat kegiatan tahunan yaitu ulang tahun Panglipur yang jatuh pada tanggal 8 Agustus setiap tahun. Padepokan ini juga menjadi ajang untuk menguji para calon pelatih. Padepokan ini berhadapan dengan rumah ketua umum Rd. Hj. Enny Rukmini Sekarningrat, hanya dipisahkan dengan jalan desa. Kedua, nama Panglipur berkaitan dengan suatu peristiwa yang disinyalir terjadi dalam masa pemerintahan Bupati Bandung R.A.A Martanagara (18931918).

Penelitian ini menggunakan metode pustaka dari literatur dan internet maupun wawancara langsung dengan pewaris Perguruan Panglipur dan beberapa orang muridnya.

Penggunaan data yang tersedia kemudian dipadukan dengan penelitian lapangan. Dengan demikian laporan penelitian ini nantinya akan berbentuk deskripsi tentang sejarah Perguruan Silat Panglipur.

Data yang didapat kemudian diolah bersama sesuai dengan metode atau prosedur penelitian yang menjadi acuan kerja. Metode yang dimaksud 
adalah metode penelitian dan penulisan sejarah seperti yang diuraikan Louis Gottschalk yaitu Heuristik, Kritik Eksteren, Kritik Intern, dan Historiografi (Gottschalk. 1986:34). Kuntowijoyo menyebut metode sejarah sebagai caracara penelitian dan penulisan sejarah melalui langkah-langkah dalam pemilihan topik, pengumpulan sumber, kritik intern dan ekstern, analisis dan interpretasi, dan penyajian dalam bentuk tulisan (Kuntowijoyo. 1999:81).

\section{B. HASIL DAN BAHASAN}

Pencak Silat adalah hasil budaya manusia Indonesia untuk membela/ mempertahankan eksistensi ( k e mandirian ) d a n integritasnya (manunggalnya) terhadap lingkungan hidup/ alam sekitarnya untuk mencapai keselarasan hidup guna meningkatkan iman dan taqwa kepada Tuhan Yang Maha Esa.(www.wikipedia. org. tanggal 12 Maret 2009)

Pencak silat ialah sistem yang terdiri atas sikap (posisi) dan gerak-gerik (pergerakan). Ketika seorang pesilat bergerak sewaktu bertarung, sikap dan gerakannya berubah mengikuti perubahan posisi lawan secara berkelanjutan. Setelah menemukan kelemahan pertahanan lawan, maka pesilat akan mencoba mengalahkan lawan dengan suatu serangan yang cepat.

\section{Lahirnya Panglipur}

Abah Aleh dilahirkan tahun 1856 di Kampung Tutul sekarang masuk dalam wilayah Desa Citeras Kecamatan Rangkasbitung Provinsi Banten. Abah
Aleh masih keturunan Sunda sebab ayahnya orang Banten dan ibunya berasal dari Kampung Sumursari sekarang masuk wilayah Desa Sukasono Kecamatan Sukawening Kabupaten Garut.

Aleh muda menggemari seni silat sehingga kemudian melakukan perantauan ke daerah Batavia, Cianjur, dan Bandung. Di tempat-tempat tersebut dipelajarinya beragam jurus silat kepada pendekar-pendekar besar seperti: Raden Agus untuk memperdalam ilmu Cimande Kampung Baru; dari $\mathrm{H}$. Bajuri ditekuninya Tepak Dua Cimande dan Sipecut; dari Gan UU dipelajarinya jurus Jalan Cikalong; dari Rd. Enggah Ahmad dipelajarinya gerak Jalan Muka; dari Rd. Kosasih dia memperoleh jurus Ulin Sabandar (termasuk juga jurus Si Pitung dan lima rangkaian jurus Alip Bandul); dan dari Rd. Husen Natadiningrat diperolehnya permainan Bojong Herang. Keseluruhan jurus-jurus yang dipelajarinya kemudian diramu sehingga menjadi jurus-jurus yang sering diperagakannya ketika melatih beberapa orang yang berguru kepadanya.

Abah Aleh kemudian mendirikan grup seni ibingan yang belum memiliki nama resmi selain disebut Ibingan Abah atau Ibingan Aleh. Grup seni ini biasanya pentas jika ada acara hajatan seperti perkawinan, sunatan dan sebagainya (Rukmini, wawancara, 29 April 2009). Nampaknya nama dan aktifitas ini berlangsung hingga tahun 1909 setelah Abah Aleh mendirikan Perguruan Silat Panglipur.

Suatu peristiwa menarik terjadi menjelang diresmikannya nama Panglipur sebagai nama Perguruan Silat yang diasuh oleh Abah Aleh. Majalah Duel mengisahkan peristiwa sakitnya Bupati Bandung Wiranatakusumah yang 
kemudian berkehendak untuk dihibur oleh pencak silat Abah Aleh dan tembang Cianjuran pimpinan Hamim. Merasa terhibur, bupati Wiranatakusumah memberikan penghargaan kepada keduanya yaitu kepada Abah Aleh diberi nama "Panglipur Galih" yang artinya penghibur hati dan kepada Hamim diberi nama "Panglipur" saja yang artinya penghibur (Majalah Duel No. 4 edisi Januari 2001).

Lebih lanjut Majalah Duel menulis bahwa terjadi kesepakatan kemudian antara Aleh dan Hamim perihal perubahan nama, nama Panglipur yang diberikan bupati kepada Hamim ditukar dengan Panglipur Galih yang diberikan kepada Aleh. Hingga sejak itu nama perguruan silat Abah Aleh menjadi Panglipur (kemudian HPS Panglipur) sedangkan nama grup tembang Cianjuran Hamim menjadi Panglipur Galih.

Menurut penulis, jika merujuk pada kelahiran Panglipur pada tahun 1909, maka tidak satu pun Bupati Bandung yang bergelar Wiranatakusumah yang cocok masa jabatannya dengan kelahiran Panglipur. Akan tetapi yang masuk kriteria adalah masa pemerintahan R.A.A Martanagara (1893-1918) Bupati Bandung kesepuluh. Sehingga dapat dipastikan bahwa nama Panglipur diberikan oleh Martanagara bukan Wiranatakusumah.

Bisa saja menyebut masa Wiranatakusumah yaitu bupati ke-7, R.A Wiranatakusumah III atau dikenal dengan Dalem Karang Anyar, yang memerintah Kabupaten Bandung dari tahun 1846 sampai 1874. Akan tetapi rasanya terlalu jauh waktu yang ditempuh antara penamaan Panglipur dengan kelahiran Panglipur yaitu sekitar 35 tahun (1874-1909), itupun mengambil tahun akhir masa jabatan Dalem Karang Anyar 1874.

\section{Perkembangan}

\section{a. Di Indonesia}

\section{- 1909-1950}

Pada tahun 1909 Abah Aleh (59) mendirikan perguruan Pencak Silat Panglipur di Kotamadya Bandung tepatnya di Gang Durman yang berada di sekitar Pasar Baru Bandung, kemudian pindah ke Jl. Imam Bonjol No. 38 (lihat gambar bendera Panglipur).

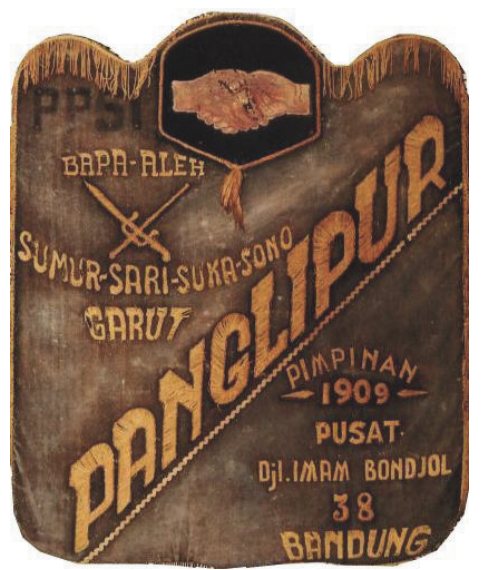

Suasana ketika Panglipur didirikan penuh dengan ketegangan karena gerakan kebangsaan telah terjadi terutama pasca Indische Vereeniging atau Perhimpunan Hindia yang kemudian menjadi Perhimpunan Indonesia di Belanda mengemukakan keinginan untuk menjadikan Indonesia sebagai sebuah negara merdeka. Peristiwa tahun 1908 tersebut kemudian merambah Hindia Belanda. Nasionalisme dan patriotisme semakin mengemuka dengan didirikannya organisasi Boedi Oetomo pada tanggal 20 Mei 1908. Akibatnya kecurigaan pemerintah Hindia Belanda akan kemungkinan terjadinya 
pemberontakan sangat mendasar, sehingga berbagai perkumpulan masyarakat mendapat pantauan, tidak terkecuali perguruan silat.

Pantauan ketat pemerintah Hindia Belanda menjadikan Abah Aleh mendirikan Panglipur dalam sebuah gang yaitu Gang Durman yang berlokasi di sekitar pusat kegiatan perekonomian Kota Bandung di Pasar Baru (Rukmini, wawancara, 29 April 2009). Kalau terlihat ada keramaian oleh mata-mata Belanda, maka tidak lama kemudian akan datang pasukannya menggrebek dan membubarkan kerumunan tersebut dan yang menjadi pemimpin pasti ditangkap. Oleh karena itu latihan silat dilakukan sembunyi-sembunyi(Rukmini, wawancara, 29 April 2009).

Semakin hari semakin banyak orang yang berminat untuk menjadi murid Panglipur. Akhirnya Abah Aleh memindahkan pusat pelatihan ke J1. Imam Bonjol No. 38 Bandung. Kegiatan masih dilakukan dengan sembunyisembunyi misalnya jika ada yang sedang berlatih maka beberapa murid berkumpul di depan rumah layaknya kumpulan para pedagang yang sedang mempersiapkan barang dagangannya. Hal itu berlangsung hingga diproklamirkannya kemerdekaan Indonesia, 17 Agustus 1945.

Tiga puluh enam tahun kemudian tepatnya pada tahun 1945 Abah Aleh pindah ke Kampung Sumursari Desa Sukasono Kecamatan Sukawening Kabupaten Garut. Kepindahan ini tampaknya berkaitan dengan ekskalasi politik Kota Bandung pada saat itu, dimana pasca proklamasi kemerdekaan RI gejolak politik dan keamanan dalam negeri sedang memanas karena kehadiran pasukan sekutu dan adanya keinginan Belanda untuk mementahkan kemerdekaan Indonesia serta sikap seluruh rakyat Indonesia yang bersiap mempertahankan kemerdekaan. Untuk Kota Bandung sendiri puncaknya adalah peristiwa Bandung Lautan Api (24 Maret 1946), setahun setelah Abah Aleh pindah ke Garut. Firasat kuat seorang pendekar.

Dalam masa mempertahankan kemerdekaan Indonesia 1945-1950, pendekar-pendekar Panglipur turut berjuang membela bangsa. Tercatat dalam riwayat Panglipur nama Bunjali seorang murid Panglipur yang juga adalah suami Enny Rukmini tertangkap oleh Belanda karena dicurigai sebagai pemberontak (dalam kacamata Indonesia disebut pejuang) oleh karena keadaan inilah ibu muda Enny Rukmini akhirnya mengangkat senjata melawan Belanda. Ia bergabung dengan Laskar Pangeran Pakpak yang bermarkas di Wanaraja Garut di bawah pimpinan Mayor Kosasih. Dalam pasukan inilah Enny mendapat gelar baru Sekarningrat karena ia selain sebagai seorang wanita pemberani juga pendekar silat dari Panglipur. Peristiwa ini terjadi dalam tahun 1947. Dalam tahun ini juga Enny bertemu dengan suaminya Bunjali. Sebagai sesama pejuang, perpisahan tak bisa dihindari, Bunjali mendapat tugas berjuang di Cipakem dalam wilayah Kabupaten Kuningan sedangkan Enny di Ciniru. Berpisahnya tempat berjuang ini juga merupakan perpisahan seumur hidup karena Bunjali gugur di Cipakem.

Pasca Perjanjian Renville 17 Januari 1948, beberapa pejuang Indonesia melakukan konsolidasi untuk hijrah ke Jogjakarta. Enny Rukmini Sekarningrat kemudian bergabung dengan pasukan TNI pimpinan Letnan Kolonel Abimanyu dan Mayor U. Rukman. Pasukan ini melakukan hijrah ke Yogyakarta bersama 
seluruh pasukan Siliwangi yang dipimpin oleh Kolonel A.H. Nasution di sekitar bulan Februari 1949. Pada tanggal 27 Desember 1949 setelah penyerahan kedaulatan, seluruh pasukan kembali ke wilayah masing-masing. Demikian pula Bu Enny. Ia keluar dari TNI dan memilih menjadi masyarakat sipil (Rukmini, wawancara, 29 April 2009). Ketika ditanyakan apa pangkat $\mathrm{Bu}$ Enny dalam masa perjuangan tersebut, ia tidak bersedia menyebutkannya. Akan tetapi keluarnya Bu Enny dari TNI juga didasari atas pernikahannya dengan Kapten Tabrani. Ia beranggapan cukuplah suaminya saja yang menjadi anggota TNI.

\section{- 1950-2007}

Lima tahun sejak perpindahan ke Garut (1950), Abah Aleh menyerahkan pimpinan Panglipur kepada putri keempatnya, Rd. Enny Rukmini dibantu beberapa murid senior dalam mengurus dan mengembangkan Panglipur. Sebelum ke Bu Enny, kepemimpinan Panglipur pernah diserahkan kepada putra tertua Abah Aleh yaitu Udi seorang prajurit TNI Angkatan Udara berpangkat Letnan. Ia adalah kakak kandung Bu Enny. Sayang perwira muda ini meninggal dunia yang menyebabkan Abah Aleh menjatuhkan pilihan kepada Enny Rukmini.

Tahun 1950 ketika Panglipur diserahkan kepada Bu Enny, cabangcabang Panglipur telah tersebar di Jawa Barat seperti di Kabupaten Majalengka, Kuningan, Garut, Cianjur, dan Kabupaten Bandung (Ciwidey dan Lembang). Adapun di Kota Bandung telah pula berdiri cabang Panglipur seperti di Pagarsih, Babakan Jati, Buah Batu, dan Kopo.
Prestasi-prestasi yang telah ditoreh oleh Bu Enny selama memimpin Perguruan Pencak Silat Panglipur tidak selalu berjalan mulus. Pada awal kepemimpinannya, kekurangan dana untuk pelaksanaan latihan sering dialaminya sedangkan animo masyarakat luas begitu kuat untuk belajar silat. Tetapi kondisi ini tetap dihadapi Bu Enny demi lestarinya salah satu budaya bangsa Indonesia.

Tahun 1957 berdiri satu lagi organisasi yang mewadahi perguruan silat bernama PPSI atau Persatuan Pencak Silat Indonesia yang diketuai oleh Mayor Jenderal Kosasih (Pangdam Siliwangi waktu itu). Panglipur bersama perguruan silat asli Sunda lainnya ikut bergabung untuk melestarikan seni beladiri pencak silat. IPSI didirikan di Surakarta tahun 1948, sedangkan PPSI berdiri di Bandung tahun 1957. Namun demikian keberadaan IPSI di wilayah Jawa Barat baru diterima tahun 1970 ketika IPSI dan PPSI diketuai satu orang yaitu H. Suhari Sapari. (http:// www.facebook.com/Garis Paksi, tanggal 27 Mei 2009). Ketika IPSI diterima di wilayah Jawa Barat, Panglipur juga ikut bergabung sehingga Himpunan Pencak Silat Panglipur mendapat pengakuan dari pemerintah sebagai sebuah perguruan silat resmi berskala nasional.

Meskipun pusat kegiatan kepengurusan Panglipur di Jl. Imam Bonjol 38 Bandung, tetapi di rumah Bu Enny Kampung Sumursari Desa Sukasono, di Kecamatan Sukawening Kabupaten Garut juga menjadi pusat pelatihan murid Panglipur. Bangunan rumah ini dibagi dua, satu sebagai rumah tinggal dan satunya lagi sebagai tempat pelatihan $\left(10 \times 30 \mathrm{~m}^{2}\right)$. Kedua bagian rumah ini berada dalam satu atap. Kini ruanganbekastempatlatihantersebuttelah 
berfungsi sebagai bagian rumah tinggal, karena pelatihan sudah dilaksanakan di Padepokan Silat Panglipur yang terletak di depan rumah Bu Enny.

Sewaktu latihan masih dilakukan di dalam rumah Bu Enny ada sekitar 120 orang yang berlatih. "Untuk melatih silat tidak perlu ruangan luas yang penting tempat gendang pencak dan areal untuk bergerak ada" kata $\mathrm{Bu}$ Enny sambil memperlihatkan ruangan bekas tempat pelatihan tersebut yang kini menjadi tempat penyimpanan alat-alat rias pengantin (Rukmini, wawancara, 29 April 2009).

Jika pada masa lalu Bu Enny turun langsung melatih murid-murid Panglipur, sekarang aktifitas tersebut telah dilakukan murid-muridnya yang telah menjadi guru silat. Aktifitas $\mathrm{Bu}$ Enny hanya mengawasi jalannya latihan yang berlangsung secara rutin dari Sabtu malam hingga sepanjang hari Minggu. Akan tetapi pada kesempatan lain, satu bulan sekali ia melakukan penyegaran kepada para pimpinan cabang dari berbagai daerah, baik melalui gerakan silat ataupun wejangan-wejangan, termasuk membahas permasalahan intern. Rutinitas ini masih berlangsung hingga sekarang.

Regenerasi juga terus berlangsung, jika Bu Enny, Iji Hatiji, atau mereka yang telah berusia 70 tahun ke atas dapat digolongkan sebagai sesepuh Panglipur, maka murid Panglipur yang berusia antara 50 sampai 69 tahun mendapat kategori pelatih senior. Usia antara 25 sampai 49 tahun disebut pelatih dan usia dibawahnya adalah murid. Pembagian ini hanyalah rumus umum semata karena di Panglipur kesenioran seseorang ditentukan sejauh mana dia mampu menguasai Panglipur.

\section{- Jurus}

Pesilat berlatih dengan jurusjurus. Jurus ialah rangkaian gerakan dasar untuk tubuh bagian atas dan bawah, yang digunakan sebagai panduan untuk menguasai penggunaan tehniktehnik lanjutan pencak silat (buah), saat dilakukan untuk berlatih secara tunggal atau berpasangan. Penggunaan langkah, atau gerakan kecil tubuh, mengajarkan penggunaan pengaturan kaki.

Jurus-jurus pada suatu perguruan silat adalah identitas perguruan tersebut, oleh karena itu perguruan silat di Indonesia memiliki beragam jurus yang biasanya dikembangkan oleh para pendirinya. Keragaman jurus ini juga berfungsi sebagai salah satu identitas suatu perguruan silat atau paguron. Uniknya beberapa diantara jurus tersebut mengadopsi gerakan atau tingkah laku binatang seperti monyet, merpati, ular, harimau, dan sebagainya.

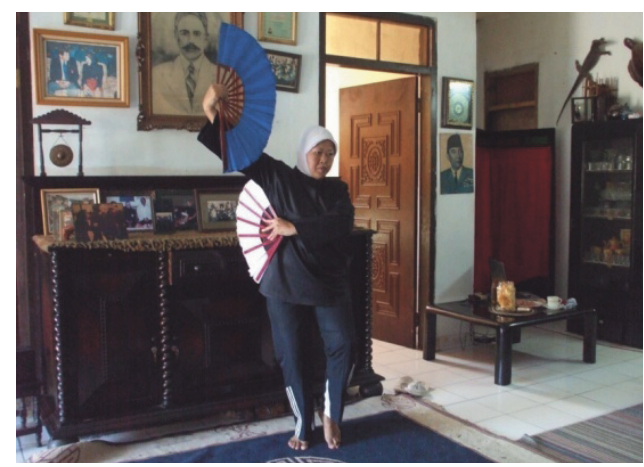

Nina (puteri Bu Enny) sedang memperagakan jurus kipas

kreasi dari Bu Enny.

Sumber: BPSNT Bandung 2009

Jurus-jurus yang ada di Panglipur berlaku seragam di setiap cabang dan paguron-paguron Panglipur lainnya di seluruh dunia. Ada dialog antara $\mathrm{Bu}$ Enny dengan Abah Aleh, ayahnya perihal 
gerakan atau jurus dalam Panglipur. Dialog tersebut berlangsung saat $\mathrm{Bu}$ Enny memperhatikan Abah Aleh sedang melatih pencak silat. Bu Enny bertanya, "Kenapa jurus-jurus Panglipur suka diberi nomor, dan semuanya tidak dibeda-bedakan, alangkah baiknya setiap tingkatan dibeda-bedakan". Katanya memberi pertanyaan pada Abah Aleh. "Agar menjadi ciri khas Panglipur, supaya ada keseragaman", lanjutnya sambil tersenyum. Pertanyaan tersebut tidak langsung dijawab Abah Aleh. Akan tetapi sebuah peristiwa akhirnya menyadarkan Bu Enny sekaligus menjawab pertanyaan tersebut, yaitu ketika Bu Enny melatih 1.600 pesilat untuk menyambut Konperensi Asia Afrika tahun 1985. Ternyata dengan gerakan yang sudah diseragamkan tidaklah sulit bagi $\mathrm{Bu}$ Enny untuk melatih ribuan orang. Ibu Enny merasa kagum kepada Abah Aleh yang bisa menyeragamkan gerakan yang begitu rumit dan bermacam-macam (Rukmini,wawancara, 29 April 2009). Lihat juga kisah pengalaman serupa dalam Majalah Duel No. 4 edisi Januari 2001).

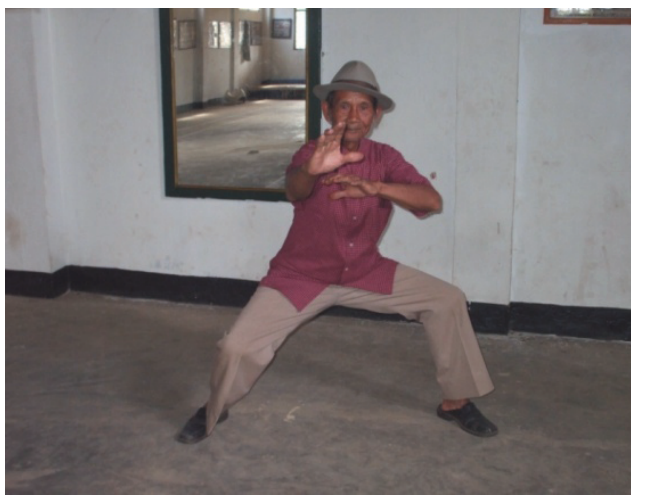

Iji Hatiji sedang memperagakan jurus pembuka

Sumber: BPSNT Bandung 2009
Jurus-jurus Panglipur menjadi acuan dalam pengajaran bagi para senior yang telah berstatus guru yang kemudian mengajarkannya kepada anggota/muridmurid baru. Pengangkatan senior menjadi seorang pelatih/guru tidaklah gampang karena selain menghapal semua jurus, juga memahami makna setiap jurus, dan padanya terdapat tanggungjawab moral terhadap jurus-jurus yang akan diajarkan. Setiap calon guru wajib mengikuti beberapa tahapan ujian yang berlangsung di hadapan para sesepuh yang dipimpin oleh ketua umum. Adapun materi dasar yang meliputi tata cara pembukaan dan penutupan latihan, tata cara pelaksanaan latihan, serta tata cara penghormatan dalam komunikasi antaranggota sebagai ciri dan kekhasan perguruan, berlaku di seluruh Padepokan Silat Panglipur yang secara garis besarnya meliputi (Ragam Jurus Materi Dasar Himpunan Pencak Silat Panglipur, tt.):

a. Pembukaan dan penutupan latihan terdiri atas:

1) Cara Berdiri terdiri atas: posisi berdiri istirahat, berdiri sikep, dan berdiri siap.

2) Cara Duduk terdiri atas; duduk siap dan duduk istirahat.

3) Hormat Panglipur

4) Tata cara pembukaan dan penutupan latihan.

b. Pelaksanaan Latihan meliputi gerak pemanasan dan pelenturan tubuh terdiri atas: senam kelenturan, keseimbangan, ketahanan dan kekuatan, serta ketangkasan.

c. Dasar Tangtungan dan langkah yang merupakan gerakan posisi kaki. Dasar tangtungan dan langkah adalah dasar mengenai bagaimana mengetahui berbagai bentuk dari posisi kaki atau kuda-kuda, adeg- 
adeg (level), penyimpanan berat tubuh, langkah dan perubahannya, serta arah menghadap beserta perpindahannya. Dasar tangtungan dan langkah terdiri atas:

1) Dasar kuda-kuda ialah suatu bentuk atau posisi dasar kaki yang paling mendasar, dimana letak kedua telapak kaki diatur dengan cara membuka dan membentuk sudut 45 derajat sampai 90 derajat dengan tumit sebagai titik sudutnya.

2) Dasar adeg-adeg ialah suatu bentuk atau posisi dasar kaki yang mengatur tinggi rendah serta lebar suatu kuda-kuda dengan posisi tubuh tetap tegak.

3) Dasar obah tangtungan adalah suatu bentuk perubahan tangtungan atau gerak kaki paling mendasar, yaitu proses perpindahan posisi telapak kaki dari satu bentuk atau tempat ke bentuk dan bentuk lain

4) Dasar lengkah ialah suatu bentuk perubahan tangtungan atau gerak kaki yang dilakukan untuk membiasakan kaki melakukan perubahan posisi dari satu bentuk kuda-kuda atau adeg-adeg ke posisi kuda-kuda dan adeg-adeg yang lain.

5) Cara melangkah ialah suatu bentuk atau sistem melangkah pada saat menggunakan atau menggerakkan dasar langkah dengan tujuan untuk menghindar dari serangan lawan tanpa kehilangan jangkauan serangan balik, juga untuk menyerang dengan cepat dan tak terduga dari posisi apa pun.
6) Cara gerak adalah suatu proses dan cara gerak atau perpindahan tubuh yang digunakan pada saat melakukan dasar tangtungan dan langkah.

7) Pola langkah dasar ialah pola atau strategi dari langkah dasar yang dilakukan saat melakukan gerak. Dalam pelaksanaan latihan, tiap pola langkah dilakukan dengan melalui 3 tahap latihan, yaitu pertama, dilakukan secara satu langkah per-satu langkah; setelah itu lakukan dua langkah-dua langkah sekaligus dengan cepat; dan selanjutnya coba dengan beberapa langkah sekaligus.

8) Pola langkah adalah materi dasar yang mengatur cara dan srategi menggunakan Perubahan Bentuk Tangtungan, yang bisa menjadikan gerak lebih hidup serta berada pada situasi, kondisi, saat/waktu, dan tempat yang tepat (merenah), juga pada jarak hontal (jangkauan) serta sasaran yang tepat.

9) Pola langkah adalah materi dasar yang mengatur cara dan srategi menggunakan Perubahan Bentuk Tangtungan, yang bisa menjadikan gerak lebih hidup serta berada pada situasi, kondisi, saat/waktu, dan tempat yang tepat (merenah), juga pada jarak hontal (jangkauan) serta sasaran yang tepat.

10) Pasangan adalah sikap dan posisi tubuh pada waktu membentuk suatu gerak.

11) Perubahan arah muka adalah mengubah arah hadap muka dan pandangan sesuai dengan kebutuhan dan fungsi gerak 
yang dilakukan dengan dua cara, yaitu: Lieuk atau Cingeus (Lieuk ialah mengubah arah hadap muka sesuai dengan kebutuhan dan fungsi gerak) dan Reret atau Rindat (Reret ialah mengubah arah pandangan sesuai dengan kebutuhan dan fungsi gerak).

d. Dasar dan Unsur Gerak adalah tata gerak dasar berbentuk dorongan, lontaran, tahanan, dan tarikan dengan menggunakan lintasan dan arah lintasan. Lintasan ada dua macam, yaitu lintasan lurus dan melingkar, sedangkan arah lintasan mengarah ke atas (luhur), ke bawah (handap), ke samping dalam (jero), dan ke samping luar (luar). Dalam proses geraknya mengandalkan kecepatan, kehalusan, kelembutan, ketepatan, serta kekuatan. Dasar gerak ini selalu diawali dan diakhiri dengan sikep sampurna atau sikap pasang. Dasar gerak dikelompokkan berdasarkan bagian anggota tubuh, dengan atau tanpa senjata yang digunakan sebagai alat penyasar, yaitu alat serangan untuk dikenakan ke sasaran atau lawan.

Keempat komponen di atas selalu dilaksanakan ketika latihan akan dan sedang dilaksanakan. Poin c dan terutama $\mathrm{d}$ adalah gerak dasar jurus yang mengolah kemampuan motorik manusia yang diolah secara maksimal tetapi lembut, tegas, dan kuat.

Panglipur sebagaimana perguruan silat lainnya memiliki teknik bertahan dan menyerang. Pesilat biasa menggunakan tangan, siku, lengan, kaki, lutut, dan telapak kaki dalam serangan. Teknik umum termasuk tendangan, pukulan, sandungan, sapuan, mengunci, melempar, menahan, mematahkan tulang sendi, dan lain-lain. Artinya gerakan silat yang dilakukan seseorang sebenarnya bertujuan melumpuhkan penyerang tanpa bermaksud membunuhnya. Pembunuhan biasanya terjadi apabilakeadaan memaksa dan demi menjaga keselamatan diri sendiri terutama jika berhadapan dengan lawan yang menggunakan senjata.

\section{- Ibingan}

Aspek yang tidak kalah penting dalam pencak silat adalah unsur seni pencak yang dalam bahasa Sunda disebut ibing. Ibing Pencak Silat mempunyai pengertian adanya unsur keindahan gerak yang mempunyai tujuan akhir menjatuhkan lawan. (Rukmini,wawancara, 29 April 2009). Dengan demikian ibing lebih mengarah pada beladiri yang ditampilkan dengan gerakan indah yang sebenarnya merupakan pengolahan jurus.

Tampilan seni ibing ini menjadi lengkap bila disertai dengan alunan musik tradisional yang disebut gendang pencak. Gendang pencak (ada juga yang menyebutnya kendang pencak terdiri atas gendang induk (kendang indung), gendang anak (kendang anak), kulanter (kendang kecil), terompet (tarompet), dan goong (gong) (http://silatindonesia. com. Tanggal 27 Mei 2009).

Ketertarikan pada silat biasanya dimulai ketika ada hajatan yang memperagakan atraksi silat dan ibing. Anak-anak sangat menyukai ibing ini. Mereka kemudian mengikuti latihan yang lama kelamaan mengasah kemampuan mereka dalam bersilat.

Adapun jurus-jurus yang terdapat dalam Panglipur biasanya ditampilkan dalam bentuk ibingan berkelompok yang ditampilkan dalam pertunjukan yang bertujuan menjatuhkan lawan main. Tak 
kurang dari 26 ibingan yang terbagi dalam 3 bagian dalam aksi seni Panglipur yaitu:

a. Paleredan Jalak Pengkor atau Paleredan Satu, Paleredan Dua, Tepak Dua Selancar, Tepak Dua Sorong Dayung, Jalan Muka Satu, Jalan Muka Dua, Jalan Muka Tiga, Jalan Muka Empat, Jalan Muka Lima, Limbung Pertama, Limbung Kedua, Limbung Penutup.

b. Alip Bandul Satu, Alip Bandul Dua, Alip Bandul Tiga, Alip Bandul Empat, Alip Bandul Lima, Limbung Kedua, Limbung Penutup.

c. Cikalong Satu, Cikalong Dua, Cikalong Tiga, Cikalong Empat, Cikalong Lima, Limbung Pertama, Limbung Penutup.

Selain ketiga bagian ibingan tersebut juga terdapat 14 jurus rangkaian masing-masing: Sipecut, Pecah Alip, Pecah Gunting, Lapisan Pecah Gunting, Likuran, Si Pitung, Jurus Sepuluh Rangkaian, Jurus Gobang atau Bedog/ Golok Satu, Jurus Gobang atau Bedog/ Golok Dua, Jurus Gobang atau Bedog/ Golok Tiga, Jurus Limbuhan Satu, Jurus Limbuhan Dua, Jurus Limbuhan Tiga, Jurus Saras Satu.

Cecep Arif Rahman menuturkan dalam sebuah diskusi di situs Sahabat Silat bahwa sekalipun Panglipur terdiri dari berbagai aliran bukan berarti bahwa jurus-jurus tersebut digabungkan semua lalu diajarkan misalnya Cimande ada 33, Sera 12 lalu kemudian digabung menjadi 45 jurus, tidak seperti itu! Mungkin hanya 3 dasar pukulan (pukulan di sini bukan hanya tangan tapi termasuk kaki) dan 9 dasar jurus. Adapun pelajaran jurus rangkaian dan ibing merupakan pelengkap penegas dari bentuk-bentuk khas per aliran (http://sahabatsilat.com/ forum. Tanggal 23 April 2009).

Ketika telah menjadi 3 dasar pukulan dan 9 dasar jurus sudah sulit untuk menemukan mana yang Cimande ataupun Sera. Demikian pula aliranaliran lain. Karena dalam tiap jurus pokok sudah terkandung prinsip-prinsip semua aliran baik dalam cara gerak, lintasan gerak, cara melangkah, alat penyasar, koordinasi gerak antara tangan dan kaki serta tubuh, arah pandangan, ritme gerak, olah nafas, olah tenaga, dan yang lainnya merupakan satu kesatuan yang mencerminkan beberapa prinsip beladiri dari tiap aliran. Sehingga dalam satu jurus pokok, kita bisa mengaplikasikannya menurut aliran apa yang kita inginkan (Ibid).

Dari tulisan Cecep Arif Rahman dapat disimpulkan bahwa jurus-jurus di Panglipur memang berasal dari berbagai aliran tetapi yang menjadi intinya adalah akulturasi dari semua jurus tersebut yang akhirnya menimbulkan jurus baru. Akulturasi adalah pencampuran dua budaya atau lebih yang menghasilkan budaya baru tanpa meninggalkan identitasnya, sekalipun identitas tersebut tidak lagi menonjol.

Pencampuran dua budaya hanya merupakan simbol untuk kasus Panglipur, karena di Panglipur tidak hanya dua aliran silat yang digunakan jurus-jurusnya, tetapi berbagai aliran kemudian diramu menjadi jurus baru. Apakah bisa disebut kombinasi jurus ataupun kolaborasi jurus? Rasanya tidak juga karena sifat kombinasi ataupun kolaborasi adalah mengambil sebagian demi sebagian kemudian digabungkan. Sedangkan di Panglipur berbagai aliran yang ada diramu menjadi jurus baru. 
- Organisasi Himpunan Pencak Silat (HPS) Panglipur

\begin{abstract}
"Organisasi adalah kesatuan sosial yang dikoordinasikan secara sadar, dengan sebuah batasan yang relatif dapat diidentifikasi, yang bekerja secara terus menerus untuk mencapai suatu atau sekelompok tujuan yang telah ditetapkan."(Purwanto, et al., 2001:12).
\end{abstract}

Persyaratan organisasi seperti teori di atas juga terdapat dalam Panglipur.

Sejak bergabung dalam PPSI tahun 1957, Panglipur membentuk struktur organisasi bertingkat dari mulai pengurus pusat hingga ke cabang-cabang.
Kegunaan organisasi ini adalah menjadi pemersatu secara sosial sekaligus juga menjadi ikatan emosional dalam perguruan yang biasa dikenal dengan sebutan saudara seperguruan. Dalam persatuan tersebut dibuat aturan yang mengikat dengan berbagai ketentuan dan hukum apabila ada pelanggaran, kemudian menjadi wadah untuk mencapai tujuan. Tujuan utama dari terbentuknya organisasi Panglipur atau lebih dikenal dengan nama Himpunan Pencak Silat (HPS) Panglipur adalah melestarikan pencak silat sebagai budaya asli bangsa Indonesia, ikut serta dalam berbagai kegiatan persilatan baik dalam maupun luar negeri, dan menjadi duta bangsa pada event-event silat internasional.

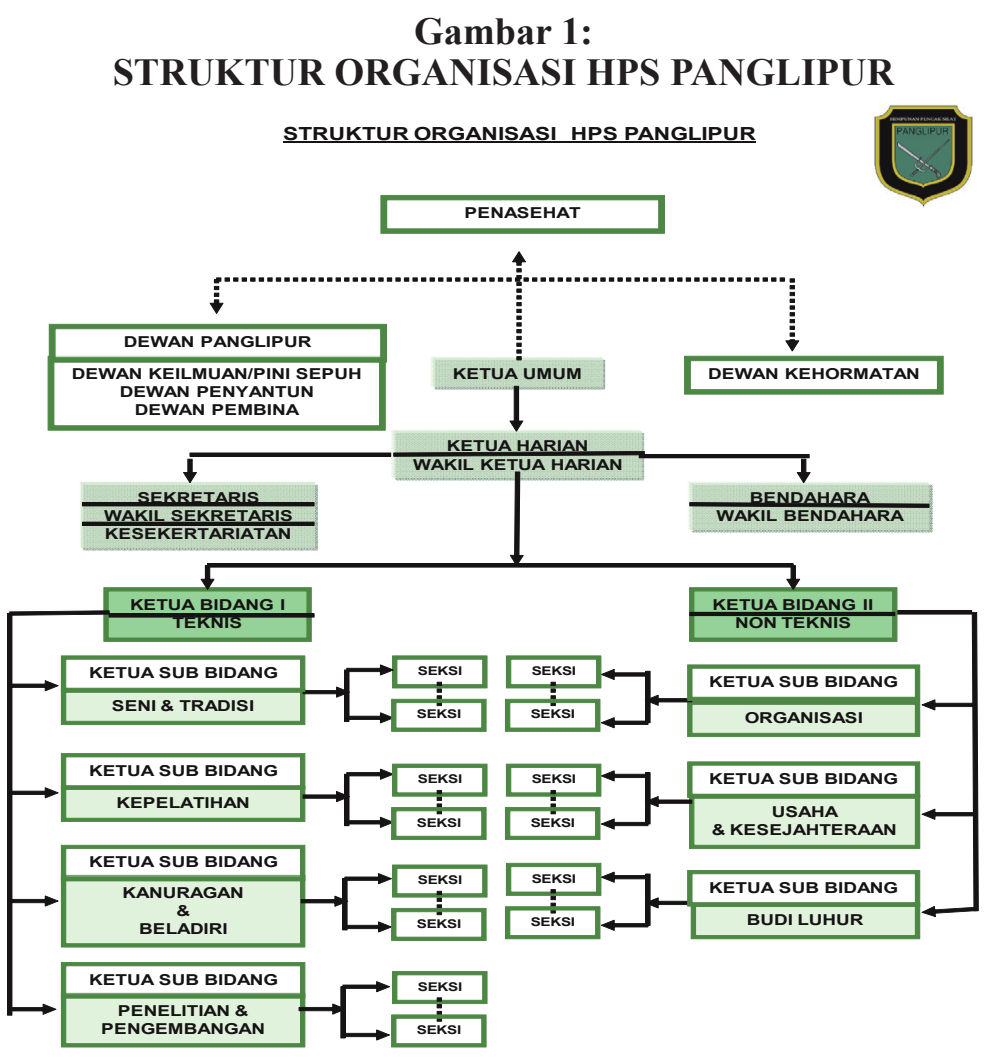


Struktur organisasi HPS Panglipur terdiri dari penasehat di tempat teratas secara koordinasi didampingi oleh 2 dewan yaitu Dewan Panglipur dan Dewan Kehormatan. Ketua umum juga berada di level ini mengomandoi ketua/wakil harian, sekretaris/wakil, bendahara/wakil, ketua bidang teknis dan nonteknis. Sementara itu bawah ketua bidang teknis terdapat 4 sub bidang, masing-masing; seni-tradisi, kepelatihan, kanuragan dan beladiri, serta sub bidang penelitian dan pengembangan. Adapun di bawah ketua bidang nonteknis terdapat 3 sub bidang, masing-masing; organisasi, kesejahteraan, dan budi luhur.

Struktur di atas adalah struktur di tingkat pusat yang ditandai dengan adanya Dewan Panglipur dan Dewan Kehormatan pada posisi koordinasi dengan Ketua Umum. Adapun Penasehat perguruan berada secara struktural tetapi tidak mengikat secara hukum. Struktur Dewan Panglipur juga diperinci sesuai proporsi masing-masing seperti terlihat pada bagan di gambar berikut.
Pada tingkat cabang juga terdapat struktur yang mengurus HPS Panglipur. Posisi jabatan struktural sama dengan bagan struktur tingkat pusat, perbedaan hanya pada tingkat dewan dimana pada struktur pusat ada Dewan Panglipur yang terdiri atas Dewan Keilmuan/Pini Sepuh, Dewan Penyantun, dan Dewan Pembina, sedangkan di tingkat cabang hanya ada Dewan Keilmuan/Pini Sepuh dan Dewan Penyantun. Posisi jabatan dalam struktur tersebut seperti terlihat pada bagan di gambar 3.

Kiprah Panglipur yang meluas dalam masa kepemimpinan Bu Enny tidak saja diisi cabang-cabang di dalam negeri tetapi juga di luar negeri. Cabangcabang Panglipur luarnegeri sebagaimana cabang dalam negeri juga menginduk pada struktur pusat HPS Panglipur. Hal ini terlihat pada bagan di gambar 4 .

Dengan demikian Panglipur merupakan perguruan silat yang telah menerapkan kepemimpinan yang modern. Struktur yang lengkap tersebut bukan hanya tertulis di atas kertas,

Gambar 2:

STRUKTUR ORGANISASI DEWAN PANGLIPUR TINGKAT PUSAT

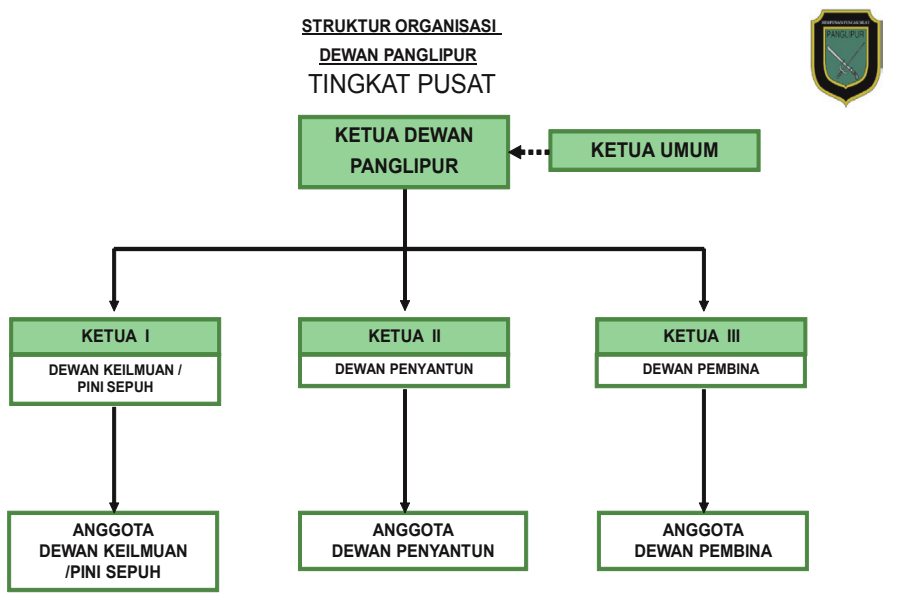

Sumber: HPS Panglipur 2009 
Gambar 3:

STRUKTUR ORGANISASI CABANG PANGLIPUR

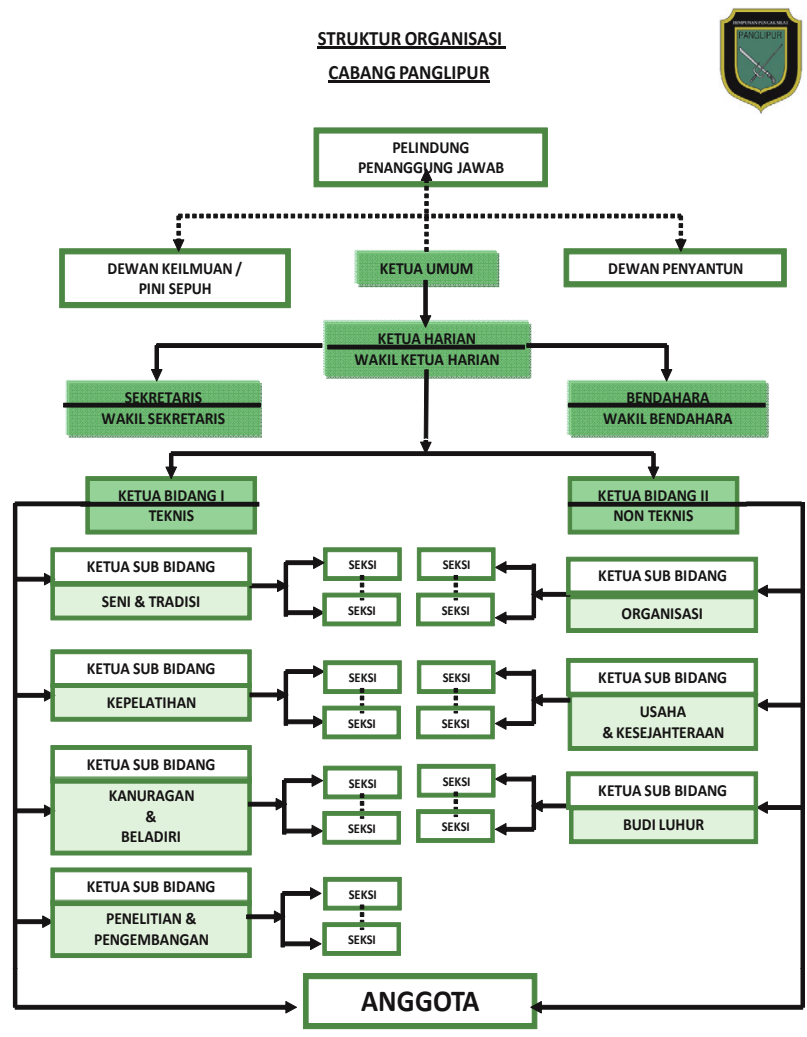

Gambar 4:

STRUKTUR ORGANISASI CABANG PANGLIPUR DALAM DAN LUAR NEGERI

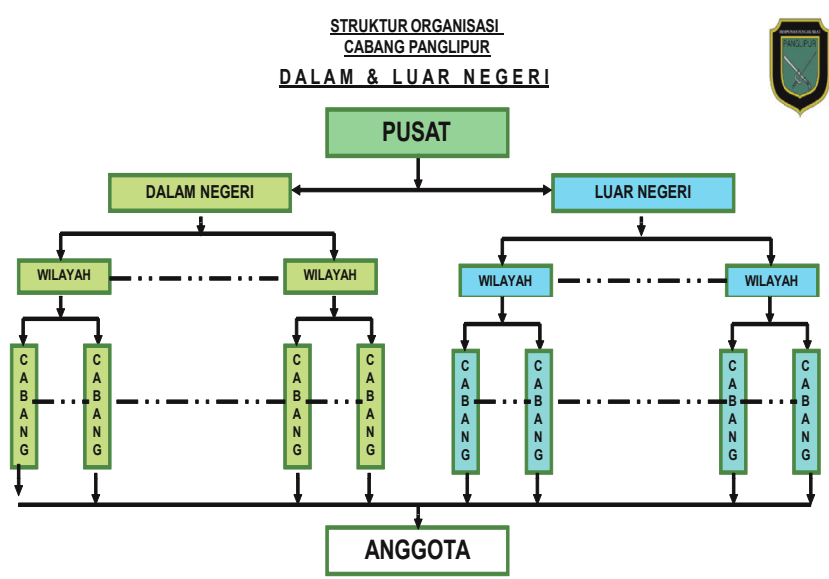

Sumber: HPS Panglipur 2009 
tetapi dalam prakteknya persatuan di antara anggota Panglipur sangat kental dan penuh persaudaraan. Hal ini dapat disaksikan jika ada event-event festival atau pertandingan, juga ketika Panglipur ulang tahun.

\section{b. Mancanegara}

Keberadaan Panglipur di mancanegara tampaknya disebabkan oleh dua hal. Pertama, ketertarikan mereka ketika sedang berlangsung pertandingan ataupun festival pencak silat sehingga mereka meminta untuk dilatih. Pada kondisi ini terkadang utusan Panglipur terpaksa harus tinggal sejenak melatih silat di negeri orang.

Kedua, dari ketertarikan tersebut orang asing datang ke tempat pelatihan Silat Panglipur, kemudian belajar silat. Mereka melakukan ini untuk jangka waktu yang lama, sehingga mereka dapat menguasai jurus-jurus yang ada di Panglipur. Ketika mereka kembali ke negara masing-masing, murid-murid Panglipur ini kemudian mendirikan cabang baru dan tidak jarang mereka mengundang guru-guru Panglipur dari Indonesia untuk mematangkan pelatihan mereka.

Cabang-cabang Panglipur di mancanegara dalam kurun waktu 59 tahun (1950 - 2009) telah merambah benua Asia, Amerika, dan Eropa. Negara-negara seperti Malaysia, Brunei, Singapura, Jepang, Arab Saudi, Belanda, Perancis, Austria, Australia, Kanada, dan sebagainya. (www.silatindonesia.com. Tanggal 29 Mei 2009).

Sampai sekarang di Negeri Belanda telah ada 5 cabang, namun yang aktif mengikuti berbagai turnamen sebanyak tiga cabang. Sebelum tahun 2005 cabang Panglipur di luar negeri terutama wilayah
Eropa adalah Belanda, Suriname, Austria negara-negara yang berdekatan dengan Belanda (www.silatindonesia.com. Tanggal 29 Mei 2009).

Event-event seperti festival silat ataupun pertandingan silat baik tingkat Asia maupun dunia menjadi ajang pertemuan saudara seperguruan. Mereka saling berbagi pengalaman dan tugas HPS Panglipur menyempurnakan gerakan silat ataupun pandangan tentang Panglipur yang kurang dipahaminya.

Barbara Regeer dan Frans Veetman adalah tokoh-tokoh yang membesarkan Panglipur di Negeri Belanda. Barbara Reeger malah telah menjadi ketua Panglipur Amsterdam setelah sejak tahun 1993 mempelajari pencak silat dari seseorang bernama Oliver yang mengajarkannya jurus-jurus yang ada di Panglipur (www.silatindonesia.com. Tanggal 29 Mei 2009).

Meneer Bek (keturunan BelandaTasikmalaya) menempa diri dengan silat Panglipur di bawah gemblengan Abah Aleh. Ilmu silat yang didapatkannya kemudian dibawanya ke Belanda. Di Belanda dia kemudian mendapatkan murid-murid baru yang berminat terhadap silat sehingga sempat membuka cabang. Cabang persilatannya diberi nama Panglipur Siliwangi (Rahman, wawancara, 29 April 2009).

Tahun 2003 dilaksanakan festival bela diri sedunia di Prancis. Pihak penyelenggara mengundang berbagai aliran beladiri langsung dari sumber/ negara asal beladiri tersebut. Misalnya Kungfu Saolin dari Cina, Karate dari Jepang, silat dari Indonesia. Peserta dari Indonesia diseleksi oleh IPSI dan yang terpilih adalah Asep yang berasal dari Panglipur bersama seorang pesilat dari Jawa Tengah dan DKI Jakarta. Sejak 
itu setiap tahun Indonesia mengirimkan perwakilan dari cabang silat dan selalu masuk 3 besar.

Asep kemudian melanjutkan kiprahnya sampai ke Vietnam, kemudian menetap di sana melatih orang-orang Vietnam sehingga pada tahun 2007 tim Vietnam mampu tampil sebagai juara pada ajang Kejuaraan se-Asia Tenggara mengungguli tim Indonesia. Asep telah kembali ke Indonesia, tetapi ia sering dipanggil ke Vietnam untuk melatih silat di sana (Rahman, wawancara, 29 April 2009).

Agus, salah satu murid senior di Panglipur dan telah memegang kepercayaan sebagai salah satu guru Panglipur mendirikan cikal bakal Panglipur di Arab Saudi. Pelatihan silat di Arab Saudi awalnya diberikan kepada warga kedutaan Indonesia di Saudi Arabia, kemudian meluas kepada warga negara tersebut (Rahman, wawancara, 29 April 2009).

Salah seorang murid Panglipur yang masih belia dan pernah pentas di Perancis dalam rangka festival silat di negara itu adalah Erik Rukmana. Erik Rukmana (17) tampil dalam kategori tarung bebas, saat usianya masih berkisar 10-11 tahun (Rukmana, wawancara, 29 April 2009).

Cecep Arif Rahman sendiri pernah mengajar silat di Perancis selama 3 bulan pada tahun 2006. Pelatihan ini diberikan atas permintaan warga Perancis yang berminat terhadap silat. Warga Perancis yang meneruskan pelatihan ini kemudian mendirikan cabang Panglipur di sana. Sampai tahun 2009 tercatat telah ada 60 orang yang menjadi warga Panglipur di Perancis. Cecep Arif Rahman mulai mempelajari silat di Panglipur dari sejak usia 8 tahun sehingga dari usia sekarang 37 tahun berarti telah 29 tahun dia menggeluti dunia persilatan di bawah panji Panglipur cabang Sukaratu yang dipimpin oleh Aki Aksan. Aki Aksan lah yang mempertemukannya dengan Bu Enny. Sejak itu Cecep serius berlatih silat di bawah gemblengan Bu Enny dimana pada waktu itu usia Cecep 16 tahun (Rahman, wawancara, 29 April 2009).

\section{PENUTUP}

Perguruan Silat Panglipur adalah salah satu wadah pelestari budaya bangsa Indonesia. Sejak kehadirannya melalui kreatifitas Abah Aleh sang pendekar pionir dan diresmikan menjadi paguron pada 8 Agustus 1909, jejak rekam sejarah bagi panglipur, para sesepuh, pelatih, dan murid-muridnya ditambah lagi dengan cabang-cabang perguruan yang tersebar di mancanegara telah mewariskan budaya asli Indonesia sekaligus mengembangkannya di luar wilayah NKRI. Kiprah Panglipur patut dihargai karena menjadikan salah satu aset Indonesia di bidang budaya lokal yaitu silat merambah mancanegara membawa nama Indonesia melanglang buana.

Tahun 2009 genap satu abad usia Panglipur. Para pendekar Panglipur tetap mempertahankan nilai yang terkandung dalam perguruan ini yaitu persaudaraan, kekeluargaan, dan kasih sayang di samping gerak jurusnya yang begitu tegas dan ampuh. Usia satu abad juga mengisi Panglipur dengan banyak cerita sejarah, mulai dari ketika bangsa Indonesia masih dalam kungkungan penjajah, menjadi bangsa mandiri, dan masa pembangunan sekarang. Patut menjadi bagian dari catatan sejarah, 
pendekar Panglipur pernah berjuang mempertahankan kemerdekaan seperti dalam episode perjuangan $\mathrm{Rd}$. $\mathrm{Hj}$. Enny Rukmini Sekarningrat, pejuang wanita yang kemudian menjadi pewaris Panglipur di tengah kecamuk batinnya yang sebenarnya menolak posisi tersebut.

Sang ayah, Abah Aleh ternyata kemudian tidak salah memilih penerus. Hal itu terbukti selama dalam kepemimpinan Bu Enny, Panglipur maju dengan pesat dan para pendekarnya berhasil membuka cabang di mancanegara. Oleh karena itu Abah Aleh dan $\mathrm{Rd} \mathrm{Hj}$. Enny Rukmini Sekarningrat sangat patut disebut sebagai maestro budaya di bidang persilatan yang bisa disejajarkan dengan tokoh-tokoh besar bangsa Indonesia lainnya, seperti H.B. Jassin, Affandi, Asep Sunandar Sunarya, Idris Sardi, Rendra, Basuki Abdullah, Barli Sasmitawinata, Abdul Muin Daeng Mile, dan sebagainya. Pada tahun 2010 Menbudpar atas nama Pemerintah Indonesia menyematkan Anugerah Kebudayaan 2010 yang mengangkat Rd Hj. Enny Rukmini Sekarningrat pendekar pencak silat 4 zaman sebagai Maestro Seni Tradisi.

\section{DAFTAR SUMBER}

\section{A. Buku}

Dahlan, M. Halwi. 2002.

Tjimande Tari Kolot Kebon

Djeruk Hilir Kabupaten Lebak. Riwayat dan Perkembangannya. Laporan Penelitian. Bandung: BKSNT Bandung.
Gottschalk, Louis. 1986.

Understanding History: A Primer of Historical Method, Mengerti Sejarah, terj. Nugroho Notosusanto, Cet. V. Jakarta: UI-Press.

Kuntowijoyo. 1999.

Pengantar Ilmu Sejarah. Cet. III. Yogyakarta:Yayasan Bentang Budaya.

Lubis, Nina Herlina, M.S.,et al. 2000.

Sejarah Kota-kota Lama di Jawa Barat. Bandung: Alqaprint Jatinangor.

Purwanto, Agus Joko. et al. 2001.

Teori Organisasi. Jakarta: Universitas Terbuka.

Duel (Majalah). No. 4 edisi Januari 2001

\section{B. Situs Internet}

eprints.uny.ac.id/2418/1/BAB_1-3.doc 6 April 2011. Beladiri di Dunia.

http://id.wikipedia.org, 12 Maret 2009. Pencak Silat

www.asal-usul.com. 12 April 2009. Sejarah Bandung Lautan Api

www.silatindonesia.com. 27 Mei 2009. Ibing.

www.silatindonesia.com. 29 Mei 2009. Panglipur di Mancanegara.

\section{Wawancara}

1. Nama : Rd. Hj. Enny Rukmini Sekarningrat 
Usia : 95 tahun

Alamat : Kp. Sumursari Ds. Sukasono

2. Nama : Iji Hataji

Usia : 86 tahun

Alamat : Ds. Linggamukti

3. Nama : Cecep Arif Rahman

Usia : 37 tahun

Alamat : Ds. Sukaratu

4. Nama : Erik Rukmana

Usia : 17 tahun

Alamat : Kp. Sumursari Ds. Sukasono 